\title{
LOS LÍMITES PROBATORIOS EN LOS PROCEDIMIENTOS TRIBUTARIOS
}

[The probationary limits in tax proceedings]

\section{Eduardo Irribarra Sobarzo*}

\section{RESUMEN}

Este artículo analiza la controversia sobre la prueba admisible de rendir dentro de las instancias de impugnación de los actos dictados por el Servicio de Impuestos Internos. Específicamente, indaga si el contribuyente puede en tales instancias aportar antecedentes no solicitados específicamente por el Servicio en la etapa de fiscalización, pero que no obstante resultaban necesarios para acreditar su situación tributaria en esta última. Para responder esa pregunta en el caso del procedimiento de
ABSTRACT

This article analyzes the controversy over evidence that can be admitted in instances that challenge acts issued by the Internal Revenue Service. Specifically, it examines if the taxpayer can, in such instances, provide records not required by the Internal Revenue Service upon auditing period, notwithstanding they were necessary to prove his tax situation upon this. To answer this question, in terms of the tax complaint process, it is suggested a new interpretation of the proof limit within the article 132

RECIBIDO el 2 de noviembre 2016 y APROBADO el 20 de abril de 2017

* Abogado, Doctorando en Derecho Universidad de los Andes, Chile, Magíster en Tributación Universidad de Chile. Dirección postal: Mons. Álvaro del Portillo 12.455. Las Condes, Santiago, Chile. Dirección electrónica: eirribarrasobarzo@ gmail.com 
reclamo tributario, se propone una nueva interpretación del límite probatorio contenido en el artículo 132 inciso undécimo del Código Tributario.

Palabras Claves

Prueba - Auditoría tributaria Preclusión. paragraph eleventh of the Tax Code.

KEYWORDS

Evidence - Tax audit - Preclusion

\section{INTRODUCCIÓN}

En materia tributaria, se ha verificado que algunos contribuyentes omiten la presentación de antecedentes relevantes en la etapa de fiscalización ante el Servicio de Impuestos Internos («SII» o el «Servicio»), los cuales recién son acompañados en las etapas impugnatorias de los actos dictados por este último. Se conjetura que la razón de esta conducta es la dificultad de los contribuyentes de contar con la información requerida y contabilidad al día a la época en que son fiscalizados, o bien una razón estratégica, en el entendido de que, a diferencia del Servicio en la etapa de fiscalización, los órganos a cargo de las instancias de impugnación no contarían con el tiempo o los recursos técnicos suficientes para revisar a cabalidad tales antecedentes.

Este fenómeno ha suscitado en el foro la controversia sobre el alcance de la regla del artículo 132 inciso undécimo del Código Tributario, que impide al contribuyente aportar en el reclamo tributario ante el Tribunal Tributario y Aduanero («TTA»), aquellos antecedentes que, teniendo relación directa con las operaciones fiscalizadas, hayan sido solicitados determinada y específicamente por el Servicio al reclamante en una citación. Específicamente, la controversia es si el impedimento se extiende también a aquellos antecedentes no solicitados en tales términos por el Servicio, incluso sin mediar una citación.

Las respuestas que tanto el Fisco como los contribuyentes han elaborado para resolver tal interrogante, han sido construidas desde el punto de vista de la competencia del juez tributario para conocer de la acción de reclamación. Por un lado, la posición fiscal niega la posibilidad de aportar pruebas en los supuestos señalados, estimando que la competencia del juez se limita a verificar la validez formal de los actos objeto de impugnación (criterio denominado doctrinariamente como juicio de anulación), de manera que no es posible efectuar una nueva auditoría 
en sede jurisdiccional ${ }^{1}$; mientras que quienes responden afirmativamente, plantean que la competencia del juez es amplia, pudiendo ahondar en los hechos y en el derecho, y de esta manera, recalificar la situación tributaria de los contribuyentes sustentado incluso en nuevos antecedentes (criterio denominado como juicio de plena jurisdicción) ${ }^{2}$.

Esta controversia ha tenido un significativo impacto en el objetivo de justicia tributaria que el ordenamiento jurídico nacional tiene concebido, pues no solo implica un anhelo de los contribuyentes de que sus obligaciones tributarias se determinen con apego a los principios de la legalidad y debido proceso, sino que ha dado lugar a una cierta indefinición respecto del fin y eficacia del procedimiento de fiscalización o auditoría tributaria llevado a cabo por el Servicio de Impuestos Internos, y de las funciones que tanto este último como los demás órganos jurisdiccionales tienen para el cumplimiento de dicho objetivo.

Ahora bien, no obstante que la delimitación de la competencia del juez tributario es un asunto de vital importancia en esta materia, la solución a la controversia suscitada debiera buscarse a partir de otra interrogante, a saber, si el contribuyente tiene no solo el derecho sino además la obligación legal de acreditar su situación tributaria dentro del procedimiento de auditoría tributaria, y de ser efectivo, cuál es la consecuencia de incumplirla. Responder a estas interrogantes contribuirá no solo a resolver la cuestión sobre la admisión de prueba en la etapa jurisdiccional ante el TTA, sino que también en las etapas de revisión ante el propio Servicio, como sucede en la reposición administrativa voluntaria (RAV) y en la revisión de la actuación fiscalizadora (RAF). Y, asimismo, una solución normativa y racional a este problema contribuirá a concebir al proceso tributario de acuerdo a su correcta e idónea función de salvaguardar adecuadamente los intereses tanto de los contribuyentes como del Estado.

El presente artículo procura responder lege data estas interrogantes, planteando la siguiente tesis: si el contribuyente es requerido o citado por el Servicio de Impuestos Internos dentro de un procedimiento de fiscalización o auditoría tributaria, aquel tiene la obligación legal de aportar todos los antecedentes necesarios para acreditar su situación tributaria, incluso aquellos no solicitados en forma específica y determinada. Luego, y atendida la función y finalidad del procedimiento de auditoría tributaria,

${ }^{1}$ Ver sentencias de la I. Corte de Apelaciones de Concepción de 18 de julio de 2013 (rol 22-2013), y de Santiago de 24 de junio de 2014 (rol 41-2014).

${ }^{2}$ Ver sentencias de la I. Corte Apelaciones Santiago de 16 de diciembre de 2014 (rol 95-2014), de Valparaíso de 1 de agosto de 2014 (rol 14-2014), de Antofagasta de 12 de marzo de 2013 (rol 17-2012), y de la Excma. Corte Suprema de 15 de abril de 2015 (rol 11461-2014). 
el incumplimiento voluntario de la obligación de aportar tales pruebas, implica para el contribuyente la preclusión del derecho de aportarlas en cualesquiera de las etapas de impugnación subsecuentes. Respecto del procedimiento de reclamo tributario ante el TTA, la regla del artículo 132 inciso undécimo del Código Tributario es simplemente una regla reiterativa de una norma general, consistente en que el contribuyente debe probar únicamente en la instancia de auditoría tributaria, y no en las etapas posteriores de impugnación.

\section{El PROCEDIMIENTO DE AUDITORÍA TRIBUTARIA}

Para poder sostener que el procedimiento de fiscalización o auditoría tributaria ante el SII es la única instancia donde el contribuyente debe acreditar su situación tributaria, es necesario revisar brevemente cuál es la función del Servicio de Impuestos Internos, y asimismo, cuál es la finalidad de dicho procedimiento de auditoría.

\section{Naturaleza orgánica y funciones del Servicio de Impuestos Internos}

De acuerdo a la Ley Orgánica Constitucional de Bases Generales de la Administración de Estado ${ }^{3}$, el gobierno y la administración del Estado la ejerce el Presidente de la República con la colaboración de los órganos que establezcan la Constitución y las leyes. Estos órganos, detentan potestades públicas específicas, consistentes en poderes-deberes dirigidos a satisfacer determinados intereses o funciones públicos. La potestad administrativa «está entregada a los órganos de la Administración del Estado para satisfacer los intereses públicos puestos bajo su órbita competencial, lo que justifica, precisamente, la exorbitancia de su contenido y su fuerza coactiva con los ciudadanos $»^{4}$. De lo anterior, es posible colegir que la existencia de los órganos de la Administración se justifica únicamente en atención a la función pública que la ley les ha asignado.

El Servicio de Impuestos Internos es un órgano de la Administración del Estado, con personalidad jurídica propia, dependiente del Ministerio de Hacienda y constituido por la Dirección Nacional, su Dirección de Grandes Contribuyentes, y por las Direcciones Regionales. Se ha señalado que el Servicio «es un órgano de la administración centralizada, territorialmente desconcentrado, integrado por órganos con potestades funcionalmente desconcentradas, con patrimonio y personalidad jurídica

${ }^{3}$ Ley No 18.575 de 1986.

${ }^{4}$ Ferrada, Juan, Las potestades y privilegios de la administración pública en el régimen administrativo chileno, en Revista de Derecho 10 (2007) 2, pp. 69-94, p. 76. 
propia y sujeto a la dependencia (no jerárquica) o supervigilancia del Ministerio de Hacienda ${ }^{5}$. Sin embargo, lo cierto es que el Servicio no es un órgano centralizado sino descentralizado, en virtud de que el artículo 29 de la Ley $\mathrm{N}^{\circ} 18.575$ dispone que «los servicios centralizados actuarán bajo la personalidad jurídica y con los bienes y recursos del Fisco y estarán sometidos a la dependencia del Presidente de la República, a través del Ministerio correspondiente. Los servicios descentralizados actuarán con la personalidad jurídica y el patrimonio propios que la ley les asigne y estarán sometidos a la supervigilancia del Presidente de la República a través del Ministerio respectivo. La descentralización podrá ser funcional o territoriali. Además, la Contraloría General de la República, mediante Dictamen Nº 38.427 de 18.06.2013, señaló expresamente que el Servicio es una entidad descentralizada que pertenece a la Administración del Estado.

En su calidad de órgano de la Administración del Estado, la actuación del Servicio se debe someter a los principios de juridicidad establecidos en la Constitución Política de la República («CPR»), y a las normas contenidas en las leyes $\mathrm{N}^{\text {os }} 19.880$ sobre Bases de los Procedimientos Administrativos que rigen sus actos (LBPA), y 18.575, previamente singularizada.

Sus principales funciones se expresan en el artículo $1^{\circ}$ de su Ley Orgánica, contenida en el DFL No 7 de 1980, consistente en «la aplicación y fiscalización de todos los impuestos internos actualmente establecidos o que se establecieren, fiscales o de otro carácter en que tenga interés el Fisco y cuyo control no esté especialmente encomendado por la ley a una autoridad diferente». Dichas funciones las reitera el artículo 6 del Código Tributario, al señalar que «corresponde al Servicio de Impuestos Internos el ejercicio de las atribuciones que le confiere su Estatuto Orgánico, el presente Código y las leyes y, en especial, la aplicación y fiscalización de las disposiciones tributarias».

Por fiscalización se entiende la acción de "criticar y traer a juicio las acciones u obras de alguien ${ }^{6}$. Aplicado aquel término a la función propia del Servicio, se puede señalar que la función de fiscalización consiste en el análisis de la situación tributaria de los contribuyentes, conjuntamente con la verificación del cumplimiento de las diversas obligaciones de que son sujetos, sean estas principales -el pago de impuestos-, como accesorias -obligaciones de declaración, información, de registro, pago de multas, etc.-. Por su parte, la función de aplicación puede definirse como la de atribución y determinación de los impuestos a que son sujetos los contribuyentes, en el evento que no hayan cumplido cabalmente las obligaciones

5 ZuRITA, Milenko, El acto administrativo tributario (Santiago, Editorial Libromar, 2013), p. 97.

${ }^{6}$ Según se define «fiscalizar» por el Diccionario de la lengua española. 
mencionadas. No obstante las diferencias entre una y otra función, para los fines de este artículo, se comprenderán ambas dentro de la función de fiscalización.

Para cumplir su función fiscalizadora, su ley orgánica y el Código Tributario le asignan al Servicio diversas atribuciones, como la entregada a su Director Nacional de interpretar administrativamente las disposiciones tributarias, fijar normas, impartir instrucciones y dictar órdenes para la aplicación y fiscalización de los impuestos; o a sus Directores Regionales de resolver administrativamente todos los asuntos de carácter tributario que se promuevan, incluso corregir de oficio, en cualquier tiempo, los vicios o errores manifiestos en que se haya incurrido en las liquidaciones o giros de impuestos. Asimismo, y siempre orientado al cumplimiento de su función, diversas normas conceden al Servicio facultades para exigir de los contribuyentes el cumplimiento de diversas obligaciones, como son ciertos registros y libros especiales, sistemas determinados de contabilidad, medidas de apremio por incumplimientos de diversas obligaciones, envío de informaciones, etc. Lo anterior, sin perjuicio de que diversas normas ya exigían a los particulares el cumplimiento de obligaciones de información, destacando la contemplada en el artículo 25 del Código de Comercio de llevar al día diversos libros contables, las consignadas en Párrafo $2^{\circ}$ del Título I del Libro Primero del Código Tributario, relativas precisamente a la fiscalización y aplicación de las disposiciones tributarias, entre otras.

Para el cumplimiento de su función pública, el Código Tributario y la LBPA confieren al Servicio un procedimiento administrativo reglado. En dicho procedimiento, la ley -y según se explicará más adelante- obliga al contribuyente a comparecer ante la autoridad para acreditar su situación tributaria, luego de lo cual el Servicio, fundadamente, emitirá los actos terminales en los cuales se determinen las obligaciones tributarias, en el caso de existir diferencias o incumplimientos.

\section{El procedimiento de fiscalización o auditoría tributaria}

2.1. Composición del procedimiento de fiscalización o auditoría tributaria. - Por regla general, la legislación tributaria asigna al propio contribuyente el deber de cumplir sus obligaciones tributarias, sin perjuicio de que el Servicio, en atención a su función asignada, pueda fiscalizar el efectivo cumplimiento de tales obligaciones. Para llevar a cabo dicha actividad de fiscalización, el Servicio dispone de un procedimiento especial de auditoría tributaria, al final del cual puede decidir confirmar la situación tributaria declarada del contribuyente, o bien determinar las obligaciones tributarias respectivas e incumplidas. Dicho procedimiento puede comenzar con un requerimiento de informaciones al contribuyente o bien con una citación, 
y en el caso de determinarse el incumplimiento de obligaciones, culminar con la dictación de actos terminales tales como una liquidación, resolución o giro, según corresponda.

La Circular del SII No 58 de 21 de septiembre de 2000, que imparte instrucciones sobre la auditoría tributaria, la define como: «...un procedimiento destinado a fiscalizar el correcto cumplimiento por parte de los contribuyentes de su obligación tributaria principal, como también de aquellas accesorias o formales contenidas en la normativa legal y administrativa vigente, con el propósito de: 1. verificar que las declaraciones de impuestos sean expresión fidedigna de las operaciones registradas en sus libros de contabilidad $y$ de la documentación soportante, y que reflejen todas las transacciones económicas efectuadas. 2. Establecer si las bases imponibles, créditos, exenciones, franquicias, tasas e impuestos, están debidamente determinados y de existir diferencias, proceder a efectuar el cobro de los tributos con los consecuentes recargos legales. 3. Detectar oportunamente a quienes no cumplen con sus obligaciones tributarias. Se consideran auditorias tributarias: i) los Programas Nacionales enviados desde la Dirección Nacional; ii) los Programas Regionales que se planifican anualmente, más las modificaciones que se decidan durante el transcurso de la realización del programa; iii) las revisiones que tienen su origen en solicitudes de devoluciones de impuestos de los contribuyentes, como son las Devoluciones del Art. 27 Bis, IVA Exportadores o por Cambio de Sujeto (cuando estas últimas revisiones dan cuenta de al menos 6 periodos); iv) todas aquellas denuncias, verificaciones, etc., sobre las cuales el Jefe de las áreas de fiscalización determine realizar una revisión como caso de auditoría y considere al menos 6 periodos de revisión y sean notificados válidamente; $v$ ) casos de Operación Renta y Operación IVA, cuando se decide citar al contribuyente (Art.63 C.T.); vi) No concurrentes, Inversiones y otros programas especiales de Operación Renta u Operación IVA, cuando el Jefe del área de fiscalización decida efectuar un Programa Regional con estos casos».

La auditoría tributaria puede iniciarse de oficio o previa instancia del contribuyente, como sucede en los casos de solicitudes de devolución de impuestos.

Los actos que el Servicio emite y notifica al contribuyente dentro de este procedimiento son el requerimiento, la citación, la liquidación y el giro, todos los cuales se analizan a continuación.

a) Requerimiento. - Esta primera etapa de la auditoría tributaria constituye una primera comunicación entre el Servicio y los contribuyentes. Para Zurita, el requerimiento es «un acto administrativo, mediante el cual la administración manifiesta, a un contribuyente determinado, su decisión de ejercer sus facultades fiscalizadoras en un procedimiento administrativo de revisión y que produce efectos legales para la administración y para el 
contribuyente» ${ }^{7}$. Su regulación se encuentra fundamentalmente en los artículos 59, 60, 60 bis, ter, quáter, y quinquies del Código Tributario.

De acuerdo a las nuevas normas incorporadas por la Ley $\mathrm{N}^{\circ} 20.780$, es posible separar entre una etapa preliminar a la fiscalización (o etapa informativa), y otra de fiscalización propiamente tal. La diferencia entre una y otra etapa tiene relevancia para los efectos de determinar el hito que da comienzo al plazo con que cuenta el Servicio para dictar los actos terminales del procedimiento de auditoría, según dispone el artículo 59 del Código Tributario.

En la primera etapa, el Servicio puede solicitar determinados antecedentes al contribuyente dentro de un plazo que no puede exceder de un mes, con posibilidad de prórroga. Si el contribuyente en esta etapa no presenta los antecedentes requeridos, el artículo 60 del Código Tributario únicamente contempla dicha omisión como un antecedente adicional en el proceso de selección de contribuyentes para fiscalización ${ }^{8}$.

En la segunda etapa - denominada aquí de fiscalización propiamente tal, el cual constituye un acto de iniciación del procedimiento administrativo -, el Servicio otorga al contribuyente un plazo de un mes, prorrogable, para la aportación de antecedentes respecto de determinados impuestos exigibles en periodos específicos. En esta comunicación, y de acuerdo a la Circular SII No 33 de 2015, el Servicio hará constar en el requerimiento, en forma clara, el hecho de haberse dado inicio a un proceso de fiscalización al contribuyente sobre una determinada materia, indicándole el o los impuestos que se revisarán, y el o los períodos o años que se auditarán. Lo anterior, busca dar cumplimiento a lo previsto en la norma legal citada, que establece que el contribuyente tiene derecho a recibir información, al inicio de todo acto de fiscalización, sobre la naturaleza y materia a revisar. Ya en esta etapa de fiscalización, es posible advertir la obligación legal del contribuyente de probar su situación tributaria, según la voz «deberán» contenida en el siguiente pasaje del artículo 59 del Código Tributario: «cuando se inicie una fiscalización mediante requerimiento de antecedentes

7 Zurita, Milenko, cit. (n. 5), p. 250.

${ }^{8}$ Lo dicho se señala expresamente en el inciso segundo del artículo 60 del Código Tributario en los siguientes términos: «Si transcurridos los plazos a que se refiere el inciso anterior, el contribuyente no diera respuesta o esta fuera incompleta, errónea o extemporánea, ello solo se considerará como un antecedente adicional en el proceso de selección de contribuyentes para fiscalización. Sin perjuicio de lo anterior, para establecer si existen antecedentes que determinen la procedencia de un proceso de fiscalización, en los términos a que se refiere el artículo 59, el Servicio podrá requerir toda la información y documentación relacionada con el correcto cumplimiento tributario». 
que deberán ser presentados al Servicio por el contribuyente». Dicha voz «deberán» expresa una obligación en forma de mandato. Tal es el sentido que la Circular $\mathrm{N}^{\circ} 58$ citada dispone, al señalar que «si el contribuyente notificado no ha respondido ni presentado la documentación solicitada y ha vencido el plazo, se deberá efectuar denuncia por la infracción tipificada en el art. $97 N^{\circ} 6$ del Código Tributario, por entrabamiento a la fiscalización (...) Al no darse respuesta a la notificación se deberá proceder a notificar por segunda vez y bajo apercibimiento de apremio al contribuyente (...)». Continúa la Circular citada instruyendo que «si el contribuyente no da respuesta a la segunda notificación, se debe registrar dicha situación en el SIIC', a través de una anotación negativa para el contribuyente, como inconcurrente a la notificación del procedimiento de fiscalización, debiendo incorporarlo a la Nómina de Contribuyentes de Difícil Fiscalización, si es procedente. Además, debe tenerse presente que en virtud de lo dispuesto en los artículos 93, 94, 95 y 96 del Código Tributario, notificado el contribuyente por carta certificada y a lo menos para el quinto día contado desde la fecha que se entiende por recibida, por segunda vez y bajo apercibimiento expreso de que cumpla, dentro de un determinado plazo, con las obligaciones tributarias requeridas, el Director Regional está facultado para obtener dicho cumplimiento a través de la justicia ordinaria».

La constancia en el requerimiento del impuesto y periodo a ser fiscalizado, constituye un criterio adecuadamente demarcado para distinguir qué antecedentes debe aportar un contribuyente para acreditar con suficiencia el cumplimiento de sus obligaciones tributarias, no siendo necesario especificarlos en dicha comunicación. Ello además se justifica por la complejidad y dinamismo de las relaciones económicas y comerciales, los nuevos medios de comunicación y la globalización, lo cual ha dado lugar a que los contribuyentes dispongan de una amplitud probatoria muy distinta a la requerida por un sistema de prueba legal o tasada, todo lo cual se señala en el artículo 21 del Código Tributario, y asimismo, se consagra en el criterio de sana crítica con la que cuenta el juez tributario para ponderar la prueba. De esta manera, resulta admisible concluir que es el contribuyente el responsable de seleccionar aquellos antecedentes necesarios para acreditar su situación tributaria dentro de un procedimiento de fiscalización. Por lo demás, esta conclusión es expresión del principio de que la carga probatoria en materia tributaria, corresponde en primer lugar al contribuyente.

En esta misma línea, el artículo 21 del Código Tributario dispone

${ }^{9} \mathrm{El}$ «SIIC» es el Sistema de Información Integrada del Contribuyente, utilizado por el Servicio de Impuestos Internos para sus funciones. 
además que «corresponde al contribuyente probar con los documentos, libros de contabilidad u otros medios que la ley establezca, en cuanto sean necesarios u obligatorios para él, la verdad de sus declaraciones o la naturaleza de los antecedentes y monto de las operaciones que deban servir para el cálculo del impuesto». El sentido del vocablo «corresponde» del artículo 21 citado, no es otro que el imperativo. A mayor abundamiento, el mismo artículo 21 hace mención a la obligatoriedad legal o reglamentaria de los contribuyentes de llevar determinados registros contables y extracontables, los cuales se constituyen en «necesarios y obligatorios» para dar cuenta de su situación tributaria.

b) Citación. - El artículo 63 del Código Tributario dispone que el Jefe de la Oficina respectiva podrá citar al contribuyente para que, dentro del plazo de un mes -también prorrogable-, presente una declaración o la rectifique, aclare, amplíe o confirme. Cabe señalar que el Servicio no se encuentra obligado a efectuar este trámite, salvo en determinadas circunstancias mencionadas en la ley. La Circular $\mathrm{N}^{\circ} 58$ citada, define esta etapa como «un medio de fiscalización que contiene los elementos necesarios para que el contribuyente tome un adecuado conocimiento de los fundamentos de hecho y de derecho que sustentan las diferencias de impuestos no prescritas que pudieran adeudarse».

Respecto de esta etapa de la fiscalización, se ha dicho que en ella el Servicio ya debiera contar con una posición respecto de la situación tributaria del contribuyente, al punto de poder fundamentarla, tanto en los hechos como en el derecho. Sin embargo, esta explicación no resulta válida para todos los casos, puesto que el mismo artículo 63 del Código Tributario autoriza a citar a un contribuyente, incluso para que «aclare» su situación tributaria, lo cual denotaría que el Servicio la desconoce incluso totalmente, y por lo mismo, carece de una posición respecto de ella.

Frente a una citación, el contribuyente debe acreditar su situación tributaria acompañando antecedentes, incluso aquellos no solicitados expresamente por el Servicio en el requerimiento o en la misma citación, pues resulta lógico que el contribuyente disponga de más información sobre sus negocios, los cuales resultarán necesarios -y obligatorios- para acreditar su situación tributaria. Esta concepción de que el contribuyente debe aportar incluso aquellos antecedentes no solicitados expresamente, se justifica plenamente en atención a la obligación legal del mismo de acreditar su situación tributaria, la cual necesariamente se efectuará con todos los antecedentes pertinentes de que disponga, y no apenas con aquellos que sean solicitados específicamente, y que corresponden a aquellos que el Servicio estima indispensable tener a la vista. Ampararse en el grado de especificidad de los antecedentes exigidos por el Servicio, constituye incluso 
una conducta atentatoria a la buena fe procesal por parte de los contribuyentes, al omitir aportarlos porque no le fueron solicitados detalladamente.

La aportación de prueba que exceda a la solicitada por el Servicio, se esboza en la Circular en referencia: «Si dio respuesta se debe efectuar el estudio de esta, pudiendo dar como resultado, lo siguiente: Si el contribuyente presenta una declaración o rectifica, aclara, amplia o aporta más antecedentes que explican satisfactoriamente todas las partidas citadas, el fiscalizador debe conciliar totalmente las observaciones reflejadas en la citación y el proceso termina poniendo en conocimiento al contribuyente del término de la Auditoría de acuerdo a lo especificado en la letra A punto i.1). ii. Cuando el contribuyente aclara parte de las partidas citadas presentando una declaración o rectificatoria, ampliando o aportando más antecedentes, el fiscalizador debe conciliar dichas partidas y por aquellas partidas no aclaradas, debe proceder a practicar la Liquidación (Art. 21, 22, 24 y 27 del C. T.)».

$\mathrm{Al}$ igual que en la etapa de requerimiento, es posible también apreciar en el trámite de la citación la obligación -y no apenas la opción- del contribuyente de acreditar su situación tributaria ante el Servicio. En primer lugar, el artículo 63 del Código Tributario plantea en términos imperativos los verbos o acciones que el Servicio puede exigir a los contribuyentes por medio de la citación, cuando dispone que el Servicio podrá «citar al contribuyente para que, dentro del plazo de un mes, presente una declaración o rectifique, aclare, amplie o confirme la anterions. La acepción jurídica de la voz «citar» del Diccionario de la lengua española, consiste en «notificar a alguien una resolución administrativa o judicial con el fin de que comparezca ante la autoridad que la dictó». De esta manera, queda más claro que la citación no es solo una solicitud de información al contribuyente, sino que constituye un emplazamien to que obliga a este a comparecer con el objeto de que acredite su situación tributaria.

c) Liquidación. - Este acto administrativo constituye por regla general, la culminación del procedimiento de auditoría tributaria llevado a cabo por el Servicio, y consiste en la determinación de impuestos, en razón de diferencias entre lo declarado o no declarado por el contribuyente y lo verificado por el Servicio. El artículo 24 del Código Tributario, dispone que «a los contribuyentes que no presentaren declaración estando obligados a hacerlo, o a los cuales se les determinaren diferencias de impuestos, el Servicio les practicará una liquidación en la cual se dejará constancia de las partidas no comprendidas en su declaración o liquidación anterion. El deber de fundamentación de este acto por parte del Servicio, constituye un requisito insoslayable para la validez jurídica del mismo, pues la liquidación constituye la posición del Servicio respecto de la situación tributaria del contribuyente. Ahora bien, tal posición no es la definitiva, puesto 
que el artículo 25 del Código Tributario dispone que «toda liquidación de impuestos practicada por el Servicio tendrá el carácter de provisional mientras no se cumplan los plazos de prescripción, salvo en aquellos puntos o materias comprendidos expresa y determinadamente en un pronunciamiento jurisdiccional o en una revisión sobre la cual se haya pronunciado el Director Regional, a petición del contribuyente tratándose de términos de giro».

Sin perjuicio del derecho del Servicio de reliquidar impuestos, de acuerdo a lo señalado en el artículo 25 citado anteriormente, la liquidación representa un acto administrativo terminal, que "constituye la culminación de la decisión administrativa» ${ }^{10}$, en este caso, resultado del procedimiento administrativo de auditoría tributaria.

d) Giro. - Este acto administrativo consiste en una orden de ingreso o de pago de una obligación tributaria. Se ha definido como «una orden escrita, dirigida a una o más personas, mediante la cual la administración financiera dispone el pago de un impuesto ${ }^{11}$. Esta orden puede ser emitida tanto por el Servicio de Impuestos Internos, como por el Servicio de Tesorerías.

El giro puede ser emitido una vez notificada la liquidación, o incluso sin haber sido emitida esta última, como ocurre con ciertas tasaciones, impuestos de recargo, retención o traslación que no hayan sido declarados oportunamente, o los demás casos que menciona el artículo 24 del Código Tributario.

e) Resolución. - Las resoluciones son actos dictados por la autoridad administrativa dotada de poder de decisión, que resuelven asuntos de su propia competencia. Este acto también se integra dentro de los actos terminales de la Administración, y su emisión resulta habitual con ocasión de solicitudes de los contribuyentes, como es el caso de la devolución de impuestos, franquicias, o de pagos provisionales por utilidades absorbidas $(\mathrm{PPUA})^{12}$.

10 Silva Cimma, Enrique, Derecho Administrativo chileno y comparado. Actos, contratos y bienes (Santiago, Editorial Jurídica de Chile, 2001), p.93.

${ }^{11}$ Massone, Pedro, Principios de Derecho tributario (Santiago, Editorial Edeval, 1979), p.223.

${ }^{12}$ En relación con las resoluciones, cabe señalar que no resulta consistente la afirmación de que estas no pueden determinar impuestos, debiendo hacerlo únicamente las liquidaciones. Lo anterior, se explica porque cuando el artículo 24 del Código Tributario dispone que ante ciertas circunstancias el Servicio practicará una liquidación, la norma no hace referencia a un acto administrativo formal en particular, sino a una obligación de determinar un impuesto, la que puede contenerse incluso en una resolución. Es decir, el sentido del artículo 24 debe entenderse en lo sustantivo y no en lo meramente formal. Esta interpretación, se identifica además con los principios administrativos de economía procedimental y no formalización. 
En el evento de que el procedimiento administrativo de fiscalización arroje diferencias de impuestos, el Servicio las determinará, sea a través de una liquidación, giro o bien mediante una resolución, según corresponda, luego de lo cual el contribuyente podrá reclamar de tales actos, presentando un recurso de reposición ante la misma autoridad, o una reclamación ante el TTA (cuya sentencia es apelable); o incluso mediante una solicitud de corrección de vicios o errores manifiestos dentro de un procedimiento de revisión administrativa de la actuación fiscalizadora (RAF) ante el mismo Servicio, este último que puede solicitarse incluso "en cualquier tiempo", como lo expresa el artículo 6 letra $\mathrm{B} \mathrm{N}^{\circ} 5$ del Código Tributario.

\subsection{Naturaleza jurídica y fines del procedimiento de auditoría tributaria}

El procedimiento de auditoría tributaria o fiscalización analizado anteriormente, se enmarca en el concepto de auditoría fiscal entendida como «un examen de si el contribuyente ha valorado y declarado su deuda tributaria y ha cumplido otras obligaciones de acuerdo con las leyes tributarias y el sistema fiscal en general» ${ }^{13}$. La auditoría del área fiscal «persigue un doble objetivo: en primer lugar, comprobar que la compañía ha reflejado adecuadamente las obligaciones tributarias, en función del devengo, habiendo provisionado correctamente los riesgos derivados de posibles contingencias fiscales, $y$, en segundo, si se ha producido su pago efectivo según los plazos y de acuerdo a los requisitos formales establecidos» ${ }^{14}$.

La relación que surge con motivo del inicio de un procedimiento de auditoría tributaria, implica una relación jerárquica entre la autoridad y el contribuyente, entre el sujeto activo y el sujeto pasivo de la obligación tributaria. Así, el procedimiento de auditoría tributaria hace nacer un vínculo jurídico entre la autoridad (el Estado, representado por el Servicio) y el contribuyente, quienes asumen diversas obligaciones. Por un lado, el Estado debe garantizar al contribuyente el debido proceso, y en especial, el derecho de audiencia, de contradicción, de aportación de pruebas, de motivación de sus actos, entre otras garantías. Por otro, y según se analizó en el subcapítulo anterior, el contribuyente se encuentra obligado a comparecer ante el Servicio, y acreditar su situación tributaria, acompañando todos los antecedentes que posea o deba poseer en virtud de sus actividades, aun cuando no hayan sido solicitados de manera específica. La obligación de aportación, debiere considerar los principios de buena fe procesal y colaborativos que se analizarán más adelante, estableciendo un umbral

13 Grampert, M. 2002. Tax Audit, p. 1 [visible en internet: http://www.worldbank.org].

${ }^{14}$ SÁncheZ, José, Teoría y práctica de la auditoría (Madrid, Editorial CDN, 1996), p. 337. 
de exigencia al contribuyente de aportar todos los antecedentes que un contribuyente diligente aportaría para aclarar su situación tributaria. Desde esta perspectiva, la valoración de dicho estándar, debiera queda sujeta a la valoración en las etapas jurisdiccionales, donde el revisor en la etapa de RAV o bien el juez tributario, deberán efectuar el análisis, primeramente, de si un determinado antecedente debió haber sido aportado por el contribuyente, incluso aunque no haya sido exigido específicamente por el Servicio. Luego, si dicho antecedente debió haberse aportado, se debe analizar la causa del incumplimiento de la aportación. De esta manera, si el contribuyente se rige por normas contables que le obligan a tener al día un determinado libro, la consecuencia de no aportarlo en la etapa de auditoría debe asumirla el contribuyente en cuanto a no poder aportarla en etapas posteriores de impugnación.

A nivel legal, el procedimiento de auditoría tributaria se encuadra en el procedimiento administrativo definido en el artículo 18 de la LBPA como «una sucesión de actos trámite vinculados entre sí, emanados de la Administración y, en su caso, de particulares interesados, que tiene por finalidad producir un acto administrativo terminal -liquidación, resolución o giro-». La conexión de este procedimiento con las normas de la LBPA se da por sus artículos $1^{\circ}$ y $2^{\circ}$, que disponen su aplicación supletoria a los servicios públicos creados para el cumplimiento de la función administrativa, como es el caso del Servicio de Impuestos Internos.

El procedimiento administrativo puede definirse como «la serie, secuencia o sucesión de actos que, dirigida a la satisfacción directa e inmediata del bien común o interés público, constituye un elemento ordenador, regulador y sistematizador del desenvolvimiento de la función administrativa del Estado» ${ }^{15}$. En el marco de dicho procedimiento, el Servicio debe cumplir un doble rol, pues debe asegurar la eficacia de la gestión de la Administración (fin de fiscalización y aplicación de impuestos), y además, debe respetar los derechos e intereses de los contribuyentes durante su transcurso (debido proceso).

En tal calidad, el procedimiento de auditoría tributaria requiere la observancia de diversos principios y garantías, donde se destacan los siguientes:

a) Principio de contradictoriedad, que garantiza al interesado el derecho de aducir alegaciones y aportar medios de prueba, debiendo el Servicio considerarlos en sus actos terminales (arts. 10, 17 letra $\mathrm{fy}$ 35, LBPA).

Este principio resguarda más concretamente la garantía constitucional del debido proceso contemplada en el artículo 19 No 3 de la Constitución

15 Comadira, Julio, Procedimientos Administrativos (Buenos Aires, Editorial La Ley, 2002), p. 3. 
Política de la República (CPR), el cual no se limita a las instancias ante los tribunales ordinarios de justicia, sino que ante todo órgano jurisdiccional o ante cualquier autoridad ${ }^{16}$.

En cuanto a la prueba, su aportación no debe ser entendida como un mero derecho del contribuye, de acuerdo a como lo concibe la LBPA, para quien «el particular debe, por eso, ser considerado un colaborador de la autoridad administrativa» ${ }^{17}$. Al contrario, y de acuerdo a como se señaló anteriormente, el Código Tributario lo contempla en materia tributaria como una obligación, al punto de que su incumplimiento, según se verá más adelante, implica la preclusión del derecho de probar en instancias de impugnación subsecuentes. En este caso, existe una aplicación por especialidad de las normas del Código Tributario, resultando para este caso inaplicable la norma meramente facultativa de la LBPA, por su carácter supletorio.

b) Principio de econo mía procedimental, cuyo objeto es la agilización del procedimiento para que la función se cumpla en el menor tiempo posible, debiendo responder a la máxima economía de medios con eficacia, y evitando trámites dilatorios (art. 9 LBPA). Este principio se enlaza con el de celeridad (art. 7 LBPA).

c) Principio conclusivo, el cual dispone que todo el procedimiento administrativo está destinado a que la Administración dicte un acto decisorio que se pronuncie sobre la cuestión de fondo y en el cual exprese su voluntad (art. 8 LBPA). Los actos decisorios del Servicio son básicamente las resoluciones, las liquidaciones y los giros, los cuales expresan el resultado de su función fiscalizadora.

d) Principio de impugnabilidad, el cual garantiza el derecho de impugnar los actos de la Administración, mediante los recursos respectivos. Para satisfacer este principio, el administrado cuenta con vías administrativas y judiciales.

A los principios explicados arriba, se suman los de escrituración, gratuidad, imparcialidad, abstención, no formalización, inexcusabilidad, transparencia, publicidad y congruencia.

Cabe señalar también la obligación de la Administración de fundar y motivar sus actos de decisión. Los motivos son «las circunstancias materiales o fácticas que antecedente y justifican la emisión del acto administrativo"18,

\footnotetext{
${ }^{16}$ Así lo declaró la Comisión de Estudios de la Nueva Constitución, en sus sesiones $\mathrm{N}^{\text {os }} 99,100$ y 112.

${ }_{17}$ Cordero, Luis, El procedimiento administrativo (Santiago, Editorial Lexis Nexis, 2003), p. 35.

${ }^{18}$ Aróstica, Iván, La motivación de los actos administrativos en el Derecho Chi-
} 
mientras que para Vergara, la motivación es la «exteriorización o expresión de los motivos o razones que han llevado al autor del acto a adoptarlo» ${ }^{19}$.

Como puede apreciarse, tanto en el requerimiento de antecedentes como en la citación, es posible concebir que el Servicio concede y garantiza al contribuyente un espacio de tiempo suficiente para que aporte los antecedentes que acrediten su situación tributaria, es decir, se garantizan, a lo menos, los derechos a audiencia y contractoriedad. Solo una vez que el Servicio ha recibido o no los antecedentes y argumentos del contribuyente dentro del plazo fijado, aquel determinará una nueva obligación tributaria para este último, si resultare distinta a la declarada o respectiva. De esta manera, se resguarda igualmente el debido proceso, el cual es también una exigencia en los procedimientos que se libran ante la Administración del Estado, fundamentado en el derecho de igualdad ante la ley y de interdicción de la arbitrariedad previsto en la propia Constitución Política de la República (art. $\left.19 \mathrm{~N}^{\circ} 2 \mathrm{CPR}\right)^{20}$.

De todo lo analizado precedentemente, es posible concluir que el procedimiento de auditoría tributaria es el instrumento idóneo para que el Servicio cumpla su función de fiscalización y aplicación de los impuestos, razón que obliga y limita a los intervinientes -órganos jurisdiccionales, Servicio y contribuyentes- a que ese fin se realice efectivamente en dicha etapa y no en otra. Es decir, la función de fiscalización y aplicación asignada al Servicio, debe reflejarse y concluir definitivamente en los actos terminales dictados al finalizar la auditoría tributaria. Las instancias posteriores a la dictación de tales actos, no pueden ser de fiscalización ni de aplicación de impuestos, sino de revisión de la legalidad de ellos, aunque no limitada meramente a un juicio de anulación, sino de plena jurisdicción, aunque de apelación limitada, según se explicará más adelante.

El grado de especificidad de los antecedentes requeridos por el Servicio en el requerimiento o en la citación, no puede implicar que aquellos no requeridos expresamente puedan omitirse en la fiscalización y reservarse para instancias subsecuentes -incluso con la aptitud de revertir las conclusiones del Servicio en sus actos terminales-, pues es en la etapa de fiscalización donde el contribuyente debe acreditar su situación tributaria. Resulta su-

leno, en Revista de Derecho de la Pontificia Universidad Católica de Valparaíso 10 (1986), pp. 499.520, p. 505.

19 Vergara, Alejandro, Control Judicial de la Motivación de los actos administrativos, en Temas de Derecho Universidad Gabriela Mistral 6 (1991) 2, pp. 117-144, p. 117.

${ }^{20}$ Ferrada, Juan, Los procesos administrativos en el derecho chileno, en Revista de Derecho de la Pontificia Universidad Católica de Valparaíso 36 (2011) 1, pp. 251-277, p. 256. 
ficiente que el Servicio comunique al contribuyente el impuesto y periodo a ser fiscalizado, para que el contribuyente identifique los antecedentes relevantes que debe aportar.

No obstante la obligación del contribuyente de aportar pruebas en la etapa de auditoría, la función del Servicio igualmente puede cumplirse válidamente sin su comparecencia, pues la obligación tributaria se determinará con los antecedentes que existan, o bien aplicando normas de tasación si correspondiere, como la contemplada en el artículo 35 de la Ley sobre Impuesto a la Renta. Sin embargo, la falta de antecedentes puede implicar que el Servicio determine una obligación tributaria inferior a la procedente, lo cual va en perjuicio de la recaudación fiscal, dando lugar a una inequidad en relación con otros contribuyentes. Lo anterior, da cuenta de que la aportación de pruebas en la etapa de fiscalización no necesariamente mira el interés del propio contribuyente, por lo que no resulta apropiado señalar que ella sea una mera carga procesal, entendida como aquella «carga de probar los hechos que se invocan como existentes, y a la carga de persuadir al tribunal del carácter discriminatorio o no discriminatorio de los hechos en cuestión»" ${ }^{21}$ o «un deber consigo mismo»" ${ }^{22}$, que de no cumplirse, solo afectará su propio interés. Lo correcto es concebir que la aportación antedicha busca satisfacer también un interés ajeno, a saber, el del Estado de obtener sus respectivos ingresos tributarios. Entonces, tal aportación no es facultativa para el contribuyente, según se señaló supra, en atención a la finalidad del procedimiento de auditoría tributaria, y a los términos imperativos utilizados por el legislador para obligar al contribuyente a acreditar su situación tributaria dentro de un procedimiento de auditoría tributaria.

En consecuencia, el incumplimiento de la obligación de aportación de pruebas en la etapa de auditoría tributaria, según se verá a continuación, se sanciona con la preclusión del derecho de aportarlas en las instancias posteriores de impugnación.

\section{LA PRECLUSIÓN PROCESAL}

\section{Concepto general}

No obstante que según se ha explicado, la finalidad del procedimiento de auditoría tributaria resulta suficiente para establecer que la prueba de la

${ }^{21}$ MuÑoz, Fernando, Estándares conceptuales y cargas procesales en el litigio antidiscriminación. Análisis crítico de la jurisprudencia sobre Ley Zamudio entre 2012 y 2015, en Revista de Derecho (Valdivia) 28 (2015) 2, pp. 145-167, p. 158.

${ }^{22}$ Rosenberg, Leo, La carga de la prueba (2a edición, Montevideo, Editorial B de F, 2002), p. 50. 
situación tributaria de los contribuyentes se agota en ella, tal afirmación puede sustentarse además en la figura de la preclusión, cuya finalidad es la de contribuir a una administración de justicia rápida, sin dilaciones indebidas, dentro de parámetros racionales, impidiendo además un nuevo juzgamiento sobre asuntos ya resueltos. El principal argumento en favor de la aplicación de la preclusión en el proceso tributario, consiste en que "con el ejercicio de determinados poderes procesales, se contribuye a la consecución de intereses públicos; es decir, el hecho de que existen derechos, facultades y potestades procesales cuyo uso facilita que se logren objetivos de interés general o común $»^{23}$.

Chiovenda entiende que la preclusión otorga mayor precisión y rapidez a la consecución de los actos del proceso, por medio de un orden en su desarrollo, y "pone límites al ejercicio de determinadas facultades procesales, con la consecuencia siguiente: fuera de esos límites esas facultades ya no pueden ejercitarse» ${ }^{24}$. Según expone Liebman, esta figura procura «asegurar al proceso un desarrollo expedito y libre de contradicciones y de retrocesos y garantizar la certeza de las situaciones procesales ${ }^{25}$.

En atención a que tanto las partes como el mismo tribunal, por razones de estrategia, pueden provocar un retorno hacia atrás en los trámites procesales, «surge la necesidad de un mecanismo que consolide los avances hacia la aplicación definitiva del Derecho y no la bloqueen (primera necesidad mediata), logrando así el concreto orden consecutivo dentro de un proceso» ${ }^{26}$.

La señalada finalidad, se logra mediante la pérdida o extinción de la posibilidad de ejercer un determinado derecho o facultad dentro de un proceso, como el de recurrir, presentar pruebas, invocar vicios, alegar, etc. De esta manera, la preclusión «obra mediante la fijación de un punto hasta el que es posible, y más allá no lo es, introducir nuevos elementos de conocimiento, proponer nuevas peticiones y excepciones ${ }^{27}$. Couture define la preclusión como «la pérdida, extinción o consumación de una facultad procesal $»^{28}$. Asimismo, resulta interesante la explicación que sobre

${ }^{23}$ Vallines, Enrique, La preclusión en el proceso civil (Madrid, Editorial Civitas, 2004), p. 111.

${ }^{24}$ Chiovenda, Giuseppe, Instituciones de Derecho Procesal Civil (traducción de G. Orbaneja, Madrid, Editorial Revista de Derecho Privado, 1936), p. 278.

${ }_{25}$ Liebman, Enrico, Manual de Derecho Procesal Civil (Buenos Aires, Editorial EJEA, 1980), p. 179.

${ }^{26}$ GANDULFO, Eduardo, Sobre preclusiones procesales en el derecho chileno en tiempo de reformas. Ensayo de una teoría general desde un enfoque valorativo, en Ius et Praxis 15 (2009) 1, pp. 121-189, p. 126.

${ }^{27}$ Chiovenda, Giuseppe, cit. (n. 24) p. 407.

28 Couture, Eduardo, Fundamentos de Derecho Procesal Civil (Buenos Aires, Editorial Depalma, 1958), p. 196. 
esta figura hace el Tribunal Supremo español: «Merced a este principio de preclusión, se consigue dejar a salvo las sorpresas que mutuamente se podrían producir los litigantes entre sí, y además, se facilita la ordenación de las actuaciones judiciales, haciendo que cada actividad procesal se desenvuelva en su correspondiente fase; pero también por virtud de él se impone a las partes la carga de no poder formular después ninguna otra alegación, o, en su caso, la de que las que se formulen posteriormente no deban ser consideradas por el órgano jurisdiccional ${ }^{29}$.

Por su parte, Regina Garcimartín explica la finalidad de la preclusión de la siguiente manera: «La preclusión obedece fundamentalmente, siguiendo la opinión de Vallines, a la necesidad de evitar que continuamente se tenga que retrotraer el proceso o realizar ajustes procedimentales (como puede ser el caso, por ejemplo, de una suspensión de una comparecencia). A ellos se podría añadir la seguridad jurídica por la que todos los sujetos procesales han de conocer qué trámites ya han transcurrido sin posibilidad de que se vuelva a hacer uso de determinadas armas procesales y cuáles pueden ser todavía utilizados por los litigantes; esto ayuda a las partes a articular convenientemente sus medios de ataque y defensa, y también permite que el juez forme el juicio adecuado de las actuaciones que van concluyendo y, por tanto, dirija mejor la comparecencia, al saber con certeza qué posibles actuaciones procesales pueden darse todavía ${ }^{30}$.

En general, la preclusión opera en tres situaciones: i) por no haberse respetado el orden preestablecido por la ley para ejercer un derecho (preclusión por vencimiento del término o plazo); ii) por hacer uso de una actividad incompatible con la ejecución de otra anterior; y iii) por haberse ejercido válidamente un derecho. La primera de las situaciones tiene importancia para el tema tratado en este trabajo.

La aplicación de la preclusión se justifica también por el respeto al derecho fundamental al debido proceso -que comprende el derecho a una pronta justicia-, y en una comprensión sistemática del proceso como instrumento o medio para alcanzar el objetivo de resolver un conflicto. Así, para invocar la preclusión, el juez o la autoridad (en el caso de un procedimiento administrativo) podrían aplicarla, teniendo presente el objetivo del proceso particular.

Sin embargo, es cierto que la aplicación deliberada de la preclusión dentro del proceso, puede dar lugar a resultados contrarios al objetivo en él, de manera que su aplicación debe ser cuidadosa. Por ejemplo, puede implicar una rigidez excesiva del proceso, una restricción injustificada del

${ }^{29}$ RA 5410, del 22 de noviembre de 1965.

${ }^{30}$ Garcimartín, Regina, Orden y preclusión en las comparecencias en los procesos civiles (2011) (visible en en http://www.uv.es/coloquio/coloquio/comunicaciones/cp10garm.pdf, p. 4. 
derecho de defensa y del debido proceso, e incluso puede impedir que el proceso llegue a una verdad material, dado que solo puede darse por cierto aquello probado dentro de un plazo determinado (verdad formal). Ahora bien, no es la institución de la preclusión el problema, sino su uso indiscriminado, de manera que resulta importante justificar su aplicación, en atención al objetivo del proceso donde opera. Y en cuanto a que la preclusión impida llevar a una verdad material, ello no implica un problema de acceso a la justicia, «de manera que la búsqueda de la verdad como base para la administración de la justicia, constituye una meta general de procedimiento, pero ella cede, hasta tolerar la eventual ineficacia del procedimiento para alcanzarla, frente a ciertos resguardos para la seguridad individual, que impiden arribar a la verdad por algunos caminos posibles, reñidos con el concepto del Estado de Derecho" ${ }^{31}$. Además, la falta de verdad material en el proceso puede deberse a una decisión de la propia parte, de no ejercer el derecho-obligación de aportar pruebas dentro de los periodos predeterminados.

Los términos y plazos de un proceso, «son puestos para el mayor orden temporal del proceso y certeza jurídica. Así, permiten que el proceso se vaya desenvolviendo en etapas o tiempos, sea que este se halle fraccionado o bien concentrado en audiencia ${ }^{32}$. Con ello, el proceso, o mejor dicho, la función que el proceso busca, no se eterniza ni menos se asigna a otros órganos. Asimismo, respeta la separación de funciones, se optimizan los recursos públicos, y además, impide reabrir el debate en otras instancias.

En cuanto a la aplicación de la preclusión, resulta acertado el análisis efectuado por Vallines de que "están dotados de efecto preclusivo los plazos procesales activos otorgados para el ejercicio de un poder siempre que un precepto legal no excluya aquel efecto; no interesa si el plazo viene fijado por horas, días, meses o años, o si el plazo tiene carácter legal, judicial o convencional, o si el plazo es improrrogable o prorrogable» ${ }^{33}$.

\section{La preclusión en el procedimiento de auditoría tributaria}

En Chile, los plazos legales son fatales. Así se desprende de lo dispuesto en el artículo 49 del Código Civil, que reza: «Cuando se dice que un acto debe ejecutarse en o dentro de cierto plazo, se entenderá que vale si se ejecuta antes de la medianoche en que termina el último día del plazo; y cuando se exige que haya transcurrido un espacio de tiempo para que nazcan o expiren ciertos derechos, se entenderá que estos derechos no nacen o expiran

${ }^{31}$ MAIER, Julio, Derecho procesal penal argentino (Buenos Aires, Editorial Hamurabi, 1989), p. 433.

32 Gandulfo, Eduardo, cit. (n. 26), p. 163.

33 Vallines, Enrique, cit. (no 23), p. 149. 
sino después de la medianoche en que termine el uiltimo día de dicho espacio de tiempo». Asimismo, el artículo 64 del Código de Procedimiento Civil expresa que ellos «son fatales cualquiera sea la forma en que se exprese, salvo aquellos establecidos para la realización de actuaciones propias del tribunal. En consecuencia, la posibilidad de ejercer un derecho o la oportunidad para ejecutar el acto se extingue al vencimiento del plazo». Lo anterior significa que «la posibilidad de ejercer un derecho o la oportunidad para ejercer el acto se extingue al vencimiento del plazo» de pleno derecho ${ }^{34}$. En materia administrativa, y con excepción de los plazos concedidos para la Administración, los plazos igualmente son fatales, pues «no cabe duda de que la teoría de los plazos fatales tiene y ha de tener plena cabida cuando se trata del ejercicio de derechos por parte de particulares que han de recurrir ante la Administración $»^{35}$.

Los plazos legales inmersos en el procedimiento de auditoría tributaria, siguen la misma fatalidad de los plazos comentados anteriormente. De esta manera, el plazo fatal que el Código Tributario establece a los contribuyentes para que dentro del procedimiento de auditoría aporten antecedentes para acreditar su situación tributaria, sea con ocasión de un requerimiento o una citación, implica que su transcurso extingue el derecho de aportarlos en otro momento, es decir, precluye.

Ahora bien, resulta esencial conocer el momento en el cual se debe entender expirado el plazo que tiene el contribuyente para aportar la prueba solicitada en el procedimiento de auditoría tributaria, con el consecuente efecto preclusivo. La respuesta a esta interrogante, dependerá de si el contribuyente fue objeto únicamente de un requerimiento de auditoría, o si se le practicó una citación, puesto que en el último caso, la ley contempla un plazo fatal expreso con anterioridad al término del procedimiento. Así, en el caso de haber requerimiento, el plazo expira en el momento en el que culmina el procedimiento de auditoría, esto es, al ser emitido el acto terminal, sea este una liquidación, resolución o giro. En el caso de haber citación, el plazo expira el último día del plazo del mes de la citación, o el del día de su prórroga, si esta fue concedida. En este segundo caso, se justifica el adelantamiento de la preclusión, atendido a que el Servicio necesita de un tiempo para analizar los antecedentes, o procurárselos, con el objeto de emitir sus conclusiones al final del procedimiento. Ahora bien, esta justificación también serviría para anticipar el término del procedi-

34 Stoenrel, Carlos, De las disposiciones comunes a todo procedimiento y de los incidentes (Santiago, Editorial Jurídica de Chile, 2010), p. 78.

35 Silva Cimma, Enrique, Derecho administrativo chileno y comparado (cuarta edición, Santiago, Editorial Jurídica de Chile, 1992), p. 68. 
miento en el caso del requerimiento, a un instante previo a la dictación de los actos terminales.

Transcurrido que sea el plazo fatal señalado, y por el efecto de la preclusión, el contribuyente ya no podrá aportar pruebas que acrediten su situación tributaria, sea incluso dentro del procedimiento de auditoría tributaria, o en las instancias de impugnación, sea ante el mismo Servicio como el TTA. Es decir, ha operado la preclusión del derecho de probar su situación tributaria, en el procedimiento de auditoría tributaria ${ }^{36}$.

La imposibilidad de acreditar en etapas posteriores, no implica una infracción al derecho de defensa del contribuyente, puesto que en el procedimiento de auditoría tributaria el contribuyente tenía la obligación legal de aportar sus pruebas, según fue explicado anteriormente, y dentro de un lapso razonable, e incluso más extenso que el contemplado en las etapas probatorias en las instancias jurisdiccionales. Y dicha obligación tiene justamente el objetivo de que la función de fiscalización y aplicación de impuestos que detenta el Servicio efectivamente la cumpla esta entidad dentro del procedimiento de auditoría, y no en los procedimientos a cargo de otros órganos en etapas subsecuentes. De esta manera, la imposibilidad probatoria que ocasiona la preclusión resulta de una decisión volun taria del contribuyente, quien renunció - por la razón que sea - a aportar su prueba dentro del procedimiento de auditoría, autorizando al Servicio a determinar su situación tributaria únicamente con la información que este dispone, acotando de esta manera la prueba que puede ser considerada en las etapas de impugnación.

Tampoco resulta admisible sostener que tal efecto preclusivo implique una indefensión al contribuyente, en el sentido de que el plazo para aportar los antecedentes en el procedimiento de auditoría sea acotado. Al respecto, si los contribuyentes se encuentran obligados por ley a llevar al día un sistema de contabilidad particular con determinados libros e informaciones, son justamente $-\mathrm{y}$ a lo menos- estos los antecedentes que deben aportar cuando sean objeto de fiscalización, incluso sin necesidad de que sean solicitados en forma expresa o nominal, pues el contribuyente no puede menos que saber cuáles resultan necesarios y suficientes. Y esto es justamente lo que sucede en otras materias, como en el Derecho del Trabajo, cuando con motivo de una citación de la Dirección del Trabajo, resulta muy improbable que el empleador no acompañe a la comparecencia los libros de remuneraciones o de asistencia, aun cuando estos no sean

${ }^{36}$ Esta afirmación no tiene antecedentes doctrinarios. Tampoco la jurisprudencia se ha referido a la preclusión, sino que solo funda la inadmisibilidad probatoria en el procedimiento de reclamo tributario en atención a la norma del artículo 132 del Código Tributario. 
solicitados expresamente. A mayor abundamiento, las normas sobre información y registro, como las relativas a normas de contabilidad, exigen que tales obligaciones se encuentren constantemente al día, de manera que su aportación dentro del procedimiento administrativo, no resulta un esfuerzo tal, cuyo costo deba ser asumido por el Servicio, al tener que dilatar su función pública incluso en otros órganos públicos.

Cabe señalar que en los casos en que el Servicio puede liquidar o girar impuestos sin citación previa ni requerimiento, como es el caso de las tasaciones contempladas en el inciso tercero del artículo $64 \mathrm{o}$ inciso cuarto del artículo 24, ambas del Código Tributario, ciertamente el contribuyente no ha contado con un procedimiento por medio del cual acreditar su situación tributaria, dado que no fue ni requerido ni citado previamente. Sin embargo, tales casos requieren entender la razón de que el Servicio opere de tal manera, y es que la ley ha concebido en ellos que la obligación tributaria se encuentra determinada, sin necesidad de un procedimiento anterior, tanto por razones eficiencia -caso de la liquidación por tasación, cuando efectivamente ha habido una enajenación, y solo se busca determinar el valor de la operación-, como sancionatorias -caso del giro de impuestos de recargo, retención o traslación no declarados oportunamente-.

A modo de epílogo, baste señalar que una forma en que opera la preclusión, es por vencimiento del término o plazo, lo cual se explica porque, según se señaló, estos contribuyen al orden temporal de un proceso y velan por la certeza jurídica. En materia tributaria, el contribuyente cuenta con un plazo legal para cumplir su obligación de acreditar su situación tributaria dentro del procedimiento de auditoría tributaria, plazo que al ser fatal, y de acuerdo al artículo 64 del Código de Procedimiento Civil, se extingue a su vencimiento mediante preclusión. Esta obligación no es solo un derecho del contribuyente o una carga procesal, sino que la misma ley la contempla como una obligación, la cual no solo mira el interés del contribuyente, sino el del mismo sujeto activo de la relación tributaria, y por qué no, de la sociedad que espera que cada uno participe en el financiamiento de los gastos públicos.

En definitiva, la tesis de que la producción de prueba se agota en la instancia de auditoría tributaria no solo se fundamenta en un argumento que atiende a la función del Servicio de Impuestos Internos y del procedimiento de auditoría, sino además en una figura procesal como la preclusión, en atención a la naturaleza fatal del plazo que posee el contribuyente para aportar pruebas dentro del señalado procedimiento de auditoría. 


\section{AlCANCE DE los RECURSOS JURISDicCiOnales}

\section{Sistema de apelación limitada de los recursos jurisdiccionales}

En la instancia de reposición administrativa voluntaria contemplada en el artículo 123 bis del Código Tributario, el órgano hacia quien se dirige este recurso, tiene como función la de «invalidar los actos contrarios a derecho» ${ }^{37}$. En la resolución que resuelva el recurso de reposición, esta «deberá pronunciarse sobre todas las cuestiones que plantee el contribuyente en su solicitud, indicando expresamente la decisión de la autoridad sobre la presentación, conjuntamente con un acabado análisis que permita un adecuado entendimiento de cómo se arribó a dicha determinación» ${ }^{38}$.

Respecto de la instancia de revisión de la actuación fiscalizadora (RAF), contemplada en el artículo 6 letra B N. 5 del Código Tributario, esta no es propiamente una instancia, sino un mecanismo de control estrictamente formal de la legalidad de los actos del Servicio ${ }^{39}$.

En otras palabras, el contribuyente solo cuenta con dos alternativas de revisión sustantiva de los actos del Servicio, a saber, la reposición administrativa voluntaria y la reclamación ante el TTA. En la etapa de la RAF, resulta improcedente que el Servicio discrepe de la valoración de los hechos y del derecho efectuados en la etapa de fiscalización, ni mucho menos se acepte la aportación de antecedentes para recalificar los hechos ya asentados en los actos terminales objeto del recurso. Solo es posible invocar la corrección de vicios o errores manifiestos, que impliquen una infracción al principio de juridicidad, salvable únicamente con una

37 Según dispone el artículo 53 de la LBPA.

${ }^{38}$ Ugalde, Rodrigo y García, Jaime, Tribunales Tributarios y Aduaneros (Santiago, Editorial Legal Publishing, 2011), p. 118.

39 Cabe señalar que el origen de la RAF buscaba cumplir una función de garantizar los derechos de los contribuyentes, pero en una época donde el recurso de reposición voluntario no existía como tal; y por su parte, el juez que conocía del reclamo tributario era el mismo Director Regional. Por ello, la comprensión actual del alcance de este mecanismo de corrección, debe establecerse considerando necesariamente los recursos actualmente existentes, y las garantías con que cuentan hoy los contribuyentes para ejercer sus derechos, debiendo limitarse, como se señaló, únicamente a un análisis de la estricta legalidad de los actos del Servicio.

En cuanto al alcance de la competencia que se otorga al Director Regional por medio del artículo 6 letra B N. 5 del Código Tributario, cabe señalar que no resulta correcta la opinión de Zurita de que aquel pueda dividirse en dos competencias, a saber, una de revisión, y otra de corrección de vicios formales [Zurita, cit. (no 7) p. 414]. Al contrario, el alcance de la competencia legal debe entenderse reunida en una sola, consistente en la revisión de aquellos vicios o errores formales manifiestos, puesto que la función de revisión ya se encuentra regulada en los procedimientos jurisdiccionales comentados. 
declaración de ineficacia. Tales vicios o errores manifiestos se mencionan, sin carácter taxativo, en las Circulares SII N ${ }^{\text {os }} 26$ de 2008 y 51 de 2005. Por lo mismo, y en atención a la función del procedimiento de auditoría y de la competencia de las instancias jurisdiccionales, resulta irrazonable que por la vía de la RAF se acepten antecedentes para valorar los hechos, incluso cuando no fueron solicitados en forma detallada dentro del procedimiento de auditoría. Así, resulta improcedente la práctica de dejar transcurrir los plazos jurisdiccionales, en la espera de que por medio de la RAF el Servicio revise nuevamente la situación tributaria de los contribuyentes, aportando antecedentes que el contribuyente decidió no aportar en la instancia de fiscalización. Ello genera una distorsión del proceso tributario, aumentando indebidamente la carga del Servicio, y generando un derroche mayor de recursos públicos. Por lo mismo, tal vez sea necesario revisar las instrucciones contempladas en las Circulares que regulan el procedimiento de RAF, para acotar su alcance, y hacerlas coexistir con los actuales recursos jurisdiccionales.

En el caso de la instancia de reclamación, los Tribunales Tributarios y Aduaneros tienen la función de resolver las reclamaciones que presenten los contribuyentes en contra de los actos terminales del Servicio, pudiendo conocer sobre la legalidad de estos, incluso en lo relativo a su mérito y conveniencia, según se señalará más adelante.

De acuerdo a lo analizado, parece quedar clara la distinción de nuestro ordenamiento jurídico entre la función fiscalizadora y la jurisdiccional. La ley ha conferido la función fiscalizadora y de aplicación aplicadora de impuestos exclusivamente al Servicio de Impuestos Internos, función que se comprende dentro de la función de gobierno y de administración asignada al Ejecutivo. Distinta es la función jurisdiccional o de revisión de los actos emitidos por el Servicio, que siempre es posterior a la función fiscalizadora, donde la ley las ha conferido tanto a ella misma -por medio de la reposición voluntaria - como a los TTA y tribunales superiores - dentro de la instancia de reclamación-.

La convivencia entre una instancia de fiscalización y otra jurisdiccional, resulta saludable y necesaria en un Estado de Derecho, en la medida de que se distingan las funciones de los órganos que cumplen tales funciones. Así, Comadira concibe que «desde el punto de vista procesal, procedimiento administrativo y procedimiento judicial, no son sino cauces procesales externos de funciones diversas: el primero, dirigido a garantizar la satisfacción con inmediatez del interés público; el segundo, encaminado a lograr la resolución de conflictos entre partes con intereses contrapuestos ${ }^{40}$. La

${ }^{40}$ Comadira, Julio, cit. (n. 15), p. 6. 
claridad sobre las distintas funciones asignadas a distintos órganos, permite conocer con mayor claridad el alcance de la competencia de los órganos involucrados.

La separación de funciones tiene el objeto, por un lado, de asignar una función propia a cada órgano público, y por otro, de evitar un derroche de recursos públicos y la duplicidad e interferencia de funciones entre diversos órganos públicos, y menos entre órganos de otros poderes del Estado. Se expresa fundamentalmente en el artículo 5 de la No 18.575, no obstante ser un principio aplicable al Estado en su conjunto, al disponer que «los órganos de Administración del Estado deberán cumplir sus cometidos coordinadamente y propender a la unidad de acción, evitando la duplicación o interferencia de funciones».

La inobservancia de este principio implicaría consecuencias perniciosas tanto jurídicas como económicas para el Estado y sus ciudadanos. En efecto, dicho fenómeno desvía recursos públicos humanos y económicos, que se destinan a una dilatada función fiscalizadora ejercida por diversos órganos públicos, incluso correspondientes a diversos poderes. Asimismo, el Estado deja de cumplir su obligación de celeridad en sus procedimientos (art. 7 LBPA), cuya lógica es que «las autoridades administrativas impriman al procedimiento la máxima dinámica posible» ${ }^{41}$, para el bien no solo del contribuyente interviniente, sino para el de la sociedad.

Por otro lado, y a juicio de este autor, los procedimientos de revisión de los actos terminales objeto de impugnación, a saber, la RAV y la reclamación ante el TTA, parecen identificarse con verdaderas instancias de pleno conocimiento o jurisdicción, más que meros recursos de estricta nulidad $^{42}$. En otras palabras, los órganos revisores no debieran limitar su conocimiento a la estricta legalidad formal del acto reclamado, sino ahondar in extenso en los hechos controvertidos, efectuando un nuevo examen del caso, eso sí, limitados por las pruebas aportadas en la etapa administrativa.

Por ello, resulta coherente con la tesis del agotamiento de la prueba en la sede de fiscalización, concebir a las instancias de revisión -sea esta ante el SII como ante el TTA- como aquellas instancias denominadas de «apelación limitada», donde el juez de la nueva instancia solo puede considerar para su examen, los antecedentes que tuvo presente el juez inferior, sin la posibilidad de que las partes puedan aportar otros. Este tipo de instancia, es utilizado en diversos países, y se opone a la de «apelación plena», donde el tribunal puede examinar el caso, con todos los materiales de hecho y

${ }^{41}$ Cordero, Luis, cit. (n. 17), p. 68.

42 En contra, la opinión de Ferrada, Juan, cit. (n. 20), p. 254 y Benavides, Álvaro, La procedencia de la nueva auditoría en el procedimiento general de reclamaciones, en Revista de Estudios Tributarios 12 (2015), 289-317, p. 311. 
probatorios que tuvo presente el tribunal de primera instancia, agregando lo materiales que las partes aporten en la nueva instancia ${ }^{43}$. La «apelación plena» tiene los siguientes inconvenientes -que ciertamente pesan más que sus ventajas-: «[...] a) trasladar el centro de gravedad de la primera a la segunda instancia; b) al consentir la interposición de demandas, excepciones y medios probatorios nuevos con toda amplitud, se desnaturaliza la función de la segunda instancia, que no es otra, como su propio nombre indica, que examinar por segunda vez lo que ha sido examinado, enjuiciar de nuevo lo que fue enjuiciado anteriormente, y no deducir ex novo lo que previamente no ha sido resuelto por un tribunal anterior, ocasionando de esta manera un fraude a las demás partes, al esquema organizativo de los tribunales de justicia y a la ya indicada finalidad de la segunda instancia. Pero además, al permitir que se formulen demandas y excepciones que pudieron haberse alegado en la primera instancia, se convierte a esta en un simple y mero ensayo preliminar de la segunda [...]» ${ }^{44}$.

Dado el alcance que de acuerdo a lo dicho deben tener los órganos que conocen las impugnaciones de los actos emitidos por el Servicio, resulta secundario e incluso inapropiado mantener vigente la discusión sobre la competencia del juez tributario, de si es de nulidad o de plena jurisdicción. Ello puesto que el revisor de una impugnación (sea este el mismo SII o el TTA) debe contar con plena jurisdicción, esto es, «conocer de las cuestiones de hecho y de derecho, y fallar la contienda declarando un derecho subjetivo, esto es, una situación jurídica determinada $»^{45}$, no limitando su competencia a la estricta legalidad formal del acto impugnado, sino únicamente en cuanto a la prueba aportada en la instancia de auditoría tributaria. En otras palabras, el órgano jurisdiccional puede conocer ampliamente de la controversia, pero limitado a la prueba aportada en la instancia de fiscalización (con excepción de la admisión de pruebas que el contribuyente no pudo aportar por razones ajenas a su voluntad).

La comprensión de las instancias de revisión como aquellas de «apelación limitada» implica necesariamente renunciar a la posibilidad de que el proceso sea un medio que siempre lleve a alcanzar la verdad material. Sin embargo, y como ya se explicó anteriormente, el proceso inevitablemente limita y condiciona la búsqueda de tal fin, dado que se confronta con la necesidad de aplicar una pronta administración de justicia y cumplir con

${ }^{43}$ Palomo, Diego, Apelación, doble instancia y proceso civil oral. A propósito de la reforma en trámite, en Estudios Constitucionales 8 (2010) 2, pp. 465-524, p. 491.

${ }^{44}$ Galán, Pedro. 1981. La prueba en segunda instancia. (visible en http://www. mjusticia.gob.es/cs/Satellite/Portal/) p. 6.

${ }^{45}$ Allesch, Johan y OBANDo, Iván, El Amparo del Derecho de Acceso a la Información Pública, en Revista Ius et Praxis 11 (2005) 2, pp. 103-155, p. 120. 
los principios que el derecho administrativo impone a la administración, maximizando los recursos públicos. Por lo demás, el efecto preclusivo en análisis, fue provocado por una decisión voluntaria del contribuyente, quien decidió no aportar en el procedimiento de auditoría los antecedentes que acrediten su verdadera situación tributaria.

\section{La buena fe procesal en materia tributaria}

Un argumento adicional para confirmar la tesis de la preclusión probatoria en el procedimiento de auditoría tributaria, es la exigencia de buena fe procesal a la que se encuentran sujetos los contribuyentes dentro de proceso el proceso tributario.

El principio de la buena fe (que como todo principio del derecho, constituye una herramienta eficaz en la argumentación jurídica) subyace y modela el ordenamiento jurídico nacional. Como principio, supone un paradigma con el cual se valora la conducta ${ }^{46}$. Constituye también «un criterio ordenador de las relaciones jurídicas [...] de conformidad con las reglas de conducta socialmente consideradas como dignas de respeto ${ }^{47}$.

La buena fe procesal considera que el proceso «no es una contienda o lucha entre partes parciales, que "pelean" por lo que creen que les corresponde, y ante un tercero imparcial, sino que ese proceso es un medio para la búsqueda de la única solución legal, la basada en la verdad objetiva, medio en el que colaboran las partes (especialmente sus abogados) y el juez; en esa colaboración el juez asume deberes, no frente a las partes, sino para con la sociedad (por ejemplo la prueba de oficio), y las partes asumen deberes (no obligaciones), principalmente el de colaborar con el juez (el deber de veracidad e integridad) ${ }^{48}$. Para el profesor Picó, la buena fe procesal es «aquella conducta exigible a toda persona, en el marco de un proceso, por ser socialmente admitida como correcta ${ }^{49}$. La buena fe procesal encuentra una justificación supra legal en las reglas del debido proceso a la luz del artículo $19 \mathrm{~N}^{\circ} 3$ inciso quinto de la $\mathrm{CPR}^{50}$.

46 Guzmán, Alejandro, La buena fe en el Código Civil de Chile, en Revista Chilena de Derecho 29 (2002) 1, pp. 11-23, p. 22

47 IruReta, Pedro, Vigencia del principio de la buena fe en el derecho del trabajo chileno, en Ius et Praxis 17 (2011) 2, pp. 133-188, p. 139.

${ }^{48}$ Montero, Juan, Los principios politicos de la nueva Ley de Enjuiciamiento Civil. Los poderes del juez y la oralidad (Valencia, Editorial Tirant lo Blanch, 2001), p. 337.

${ }^{49}$ PICO, Joan, El principio de la buena fe procesal (Barcelona, Editorial Bosch, 2003), p. 67.

${ }^{50}$ Carretta, Francesco, Deberes procesales de las partes en el proceso civil chileno: referencia a la buena fe procesal y al deber de coherencia, en Revista de Derecho (Valdivia) 21 (2008) 1, pp. 101-127, p. 119. 
Sea dentro de un procedimiento administrativo o judicial, los intervinientes deben respetar el deber de "completitud", definido como aquel que "atañe a las partes y les impone imperativamente que [...] expongan todos los hechos de los que tienen conocimiento, como también todas las pruebas que digan relación con dichos hechos ${ }^{51}$. Además, el contribuyente tiene la obligación de actuar cooperativa, lealmente y sin malicia, direccionado en todo momento su conducta al descubrimiento de la verdad de la manera más célere posible. Importante también es la aplicación del deber de colaboración procesal, el cual se funda en la buena fe procesal y precisa un esfuerzo conjunto de las partes para buscar con el juez la justa y pronta solución del litigio ${ }^{52}$.

La importancia de la buena fe procesal es tal, que algunos han planteado la aptitud de relativizar el principio nemo tenetur edere contra se (nadie está obligado a irse contra sí mismo), que se encontraría en plena decadencia, según enseñaba Couture ya por la primera mitad del siglo $\mathrm{XX}^{53}$.

El contenido y alcance esbozado de la buena fe procesal, resulta idóneo para delimitar el derecho -mal entendido como absoluto- de los intervinientes en un proceso, mediante normas axiológicas con efectos sancionatorios, como la imposibilidad de aportar prueba conscientemente omitida en sede administrativa. Esta conclusión resulta ajustada a derecho e innovadora, y se corresponde con aquella concepción contemporánea de la ciencia jurídica, basada en la "solución justa aquí y ahora», que encuentra su formulación en la pregunta por el ordenamiento justo y conduce, cabalmente, a entender el Derecho positivo, en su función de respuesta, como una parte integrante de la búsqueda del derecho ${ }^{54}$.

Como puede apreciarse, el proceso contiene un fuerte cariz axiológico, que también impone deberes conductuales a los intervinientes en orden a alcanzar una solución a un conflicto, en este caso, desde la etapa administrativa frente al Servicio. Para el cumplimiento de este deber, es innegable el rol del juez, "quien está llamado a ejercer de oficio o a requerimiento de parte una función fiscalizadora del cumplimiento de los deberes» ${ }^{55}$.

${ }^{51}$ RuAY, Francisco, Análisis critico sobre la inclusión del principio de buena fe procesal en el proyecto de código procesal civil chileno, en Revista Chilena de Derecho y Ciencia Politica 4 (2013) 3, pp. 53-82, p. 64.

52 Vallote, Daniel, Abuso del proceso por las partes, presupuestos generales, en XXI Congreso Nacional de Derecho Procesal Universidad Católica de Cuyo (2001) pp. $267-$ 285, p. 737.

53 Couture, cit. (n. 28), p. 54.

${ }^{54}$ VIeHWEH, Theodor, Tópica y Jurisprudencia (traducción de L.D.P. León, Madrid, Editorial Taurus, 1963), p. 16.

55 Carretta, Francesco, cit. (no 48), p. 112. 
De esta manera se entiende que el contribuyente, al tener la obligación de declarar y determinar sus impuestos, también tenga la obligación de acreditar su situación tributaria en la instancia pertinente, que como se dijo, es la de auditoría tributaria. El incumplimiento de esta obligación, implica necesariamente un acto de mala fe dentro del procedimiento de auditoría tributaria, pues obliga a los órganos que conocen de la impugnación de los actos emitidos por el Servicio, a evaluar nuevamente la cuestión, con todo el costo económico y temporal que ello conlleva.

Finalmente, y según se comentó anteriormente, quedará asignado al órgano jurisdiccional (RAV y TTA) la tarea de valorar si aquellos antecedentes que el Servicio no solicitó específicamente en una fiscalización, igualmente debieron haber sido acompañados por el contribuyente. No es posible simplemente acoger la admisibilidad de pruebas sin la consideración de que el contribuyente tiene la obligación legal de acreditar de la manera más completa su situación tributaria dentro del procedimiento de auditoría tributaria; y quién más que el mismo contribuyente conoce su negocio y las operaciones objeto de fiscalización.

\section{Alcance de la norma prohibitiva del artículo 132 inciso undécimo del} Código Tributario

La inadmisibilidad probatoria que en este artículo se propone para todas las instancias de revisión, no arriesga su validez frente a la norma contenida en el inciso undécimo del artículo 132 del Código Tributario, que parecería a contrario sensu autorizar en el procedimiento de reclamo ante el TTA, la incorporación de pruebas no solicitadas en forma detallada y específica en una citación por el SII.

La norma señala lo siguiente: "No serán admisibles aquellos antecedentes que, teniendo relación directa con las operaciones fiscalizadas, hayan sido solicitados determinada y específicamente por el Servicio al reclamante en la citación a que se refiere el artículo 63 y que este último, no obstante disponer de ellos, no haya acompañado en forma íntegra dentro del plazo del inciso segundo de dicho artículo. El reclamante siempre podrá probar que no acompañó la documentación en el plazo señalado, por causas que no le hayan sido imputables, incluyendo el caso de haber solicitado al Servicio prórroga del plazo original para contestar la referida citación y ella no fue concedida o lo fue por un plazo inferior al solicitado".

La norma impeditiva citada constituye una sanción a la mala fe del contribuyente $^{56}$, de la cual no debiera eximirse en el caso de que el Servicio no hubiere detallado los antecedentes en una citación, pues el contribu-

${ }^{56}$ UGalde y García, cit. (nº 38), p. 220. 
yente siempre ha tenido la obligación de aportar las pruebas en la instancia de auditoría, pruebas que en todo caso como se señaló, corresponden a documentación e información que debiera tener en su poder, al día y actualizada permanentemente.

La aplicación de la preclusión implica entender entonces que la regla general sea que el contribuyente no pueda aportar pruebas en las instancias posteriores, de manera que la norma de inadmisibilidad contenida en el artículo 132 inciso undécimo del Código Tributario bajo análisis, debe entenderse simplemente como una reiteración de dicha regla, para el caso puntual de que el Servicio haya exigido un antecedente específico en una citación, y no constituye una excepción o restricción alguna que implique entender que a falta de especificación, siempre puedan acompañarse pruebas en las etapas de impugnación. Admitir lo contrario implica desatender el fin y función del procedimiento de auditoría tributaria, y la obligación legal que tiene el contribuyente de probar en ella su situación tributaria dentro de plazos fatales.

El artículo 21 del Código Tributario, al disponer que la anulación o modificación de una liquidación, puede desvirtuarse con pruebas suficientes, en conformidad con las normas que rigen el proceso de reclamo tributario llevado ante el TTA, debe ser interpretado en este sentido. Así, las instancias de revisión deben ser concebidas de apelación limitada, y tal conclusión está en conformidad con las normas que rigen los procesos de impugnación, y representa entonces una norma concreta que regula dicha instancia de revisión. Por lo tanto, su inadmisibilidad no confronta el sentido de la norma contenida en el artículo 21, que, a mayor abundamiento, es una mera norma de reenvío.

La inadmisibilidad probatoria analizada tampoco se condice con el derecho que tienen los recurrentes de aportar pruebas, como bien lo concede el Título II del Libro Tercero del Código Tributario. En efecto, dentro de las instancias de impugnación, los contribuyentes pueden presentar todo tipo de pruebas, pero excluyendo aquellas de que disponía y no aportó en el procedimiento de auditoría tributaria.

De lo dicho, es posible entender que la norma impeditiva del artículo 132 del Código Tributario no es una norma restrictiva, sino reiterativa de una regla general, consistente en que el contribuyente debe probar únicamente dentro del procedimiento de auditoría tributaria.

\section{El derecho a la prueba y la preclusión}

Dado que el derecho a la prueba precluye para el contribuyente al término del procedimiento de auditoría tributaria, resulta pertinente analizar brevemente si dicha preclusión se adecúa al derecho constitucional 
al debido proceso o tutela efectiva consagrado en la Constitución Política de la República de Chile.

Es cierto que la preclusión puede en ciertos casos impedir el acceso a una verdad material dentro de un proceso. Sin embargo, igualmente esta figura es admisible y necesaria en un Estado de Derecho, pues garantiza otros derechos o bienes tan relevantes en la justicia como son la certeza jurídica y la celeridad. Asimismo, en materia probatoria, la preclusión simplemente constituye la consecuencia de que un interesado no haya ejercido su derecho a probar en una instancia donde contaba plenamente con ese derecho. Y en materia tributaria, ello no es solo un derecho, sino también una obligación, según se explicó.

El artículo 19 No 3 de la CPR garantiza a todas las personas, la igual protección de la ley en el ejercicio de sus derechos. Agrega su inciso quinto que "toda sentencia de un órgano que ejerza jurisdicción debe fundarse en un proceso previo legalmente tramitado. Corresponderá al legislador establecer siempre las garantías de un procedimiento y una investigación racionales y justos". Un aspecto de la racionalidad y justicia de un procedimiento, se refleja en el derecho de las personas a producir o aportar pruebas.

En materia tributaria, el derecho a la producción de pruebas se encuentra garantizado plenamente, aunque dentro del procedimiento de auditoría tributaria, justamente por el fin del mismo y la función de quien lidera dicho procedimiento (SII). En este procedimiento, el contribuyente cuenta con un lapso razonable de tiempo, incluso superior a los plazos jurisdiccionales de prueba, para acompañar los antecedentes que acrediten su situación tributaria, muchos de los cuales deben encontrarse al día y a disposición del contribuyente, según las diversas normas que imponen obligaciones al respecto. Cuenta también, según se señaló, con diversas garantías procedimentales, destacando la de controvertir y exponer sus argumentos frente a la autoridad tributaria.

Las garantías constitucionales del debido proceso no son absolutas, y admiten ser moduladas cuando ello resulta necesario para observar otras garantías y derechos. Por otro lado, el derecho a la prueba no es un derecho que pueda ser ejercido durante cualquier momento dentro de un proceso, pues implicaría un freno para la garantía de otros bienes, como los de celeridad y certeza jurídica. Y justamente este es el caso en materia tributaria, donde la prueba debe entenderse concentrada dentro del procedimiento de auditoría tributaria ante el Servicio, pues así se respetan las distintas funciones de los órganos intervinientes, el buen uso de los recursos públicos e igualmente la certeza jurídica y celeridad tanto para Estado como para los contribuyentes respecto de su situación tributaria.

En definitiva, no resulta sostenible afirmar que la preclusión del derecho 
a la prueba en materia tributaria, infrinja la garantía al debido proceso garantizado constitucionalmente, y específicamente, el derecho a la prueba. Lo correcto es afirmar que el procedimiento de auditoría tributaria simplemente organizó la época de producción de prueba, exigiendo una obligación al contribuyente de acreditar en ella su situación tributaria.

\section{CONCLUSIONes}

La obligación tributaria tiene como objeto que los contribuyentes aporten al Estado una parte de su riqueza. Para tal objeto, el Servicio de Impuestos Internos tiene por ley una función determinada, consistente en fiscalizar su cumplimiento y, si correspondiere, determinar las obligaciones tributarias incumplidas. Para llevar a cabo esta función pública, el Servicio cuenta con el procedimiento de auditoría tributaria o de fiscalización, instancia donde surge una relación procesal entre el Servicio y el contribuyente, y en la cual se garantizan diversas garantías a los contribuyentes, como de contradictoriedad, producción de prueba, plazos racionales, juridicidad y fundamentación de los actos terminales. Tanto es así, que el contribuyente cuenta incluso con dos instancias para objetar tales actos (tres, por no mencionar que la apelación constituye sin duda una instancia), a saber, la reposición administrativa voluntaria y la reclamación.

Se ha argumentado en este artículo que el procedimiento de auditoría tributaria es el instrumento idóneo y único para que el Servicio cumpla cabalmente su función. Sin embargo, para que ello realmente sea así, este procedimiento necesariamente debe ser concebido no como aquel que simplemente otorga al contribuyente el derecho a comparecer y acreditar su situación tributaria, sino además que lo obliga legalmente a hacerlo. Soslayar esto último -como se ha hecho hasta ahora-implica impedir que el Servicio cumpla su función, incluso asignándosela ilegalmente a otros órganos del Estado, con el consecuente derroche de recursos públicos y de tiempo.

Y efectivamente, según la lectura que en este trabajo se efectúa de las normas del Código Tributario que regulan el requerimiento de antecedentes y la citación, la aportación de pruebas dentro del procedimiento de auditoría tributaria no es una mera facultad o derecho, sino una obligación legal. Esta nueva concepción implica que ejercido alguno de estos actos por parte del Servicio, el Código Tributario contempla plazos legales concretos para que los contribuyentes aporten pruebas, los cuales al ser fatales, conllevan la preclusión del derecho de aportarlas en etapas posteriores.

La figura de la preclusión constituye una institución reconocida en el ordenamiento jurídico nacional, y aplicable al procedimiento de auditoría 
tributaria, pues en atención al artículo 64 del Código de Procedimiento Civil, la posibilidad de ejercer un derecho o la oportunidad para ejecutar el acto se extingue al vencimiento del plazo. El fin de la preclusión es precisamente el de contribuir a la justicia del proceso, permitiendo que un determinado procedimiento realmente contribuya a satisfacer una determinada función pública, no solo referida a la administración de justicia, sino que incluso aplicable a las funciones de los diversos órganos de administración del Estado, entre las cuales se encuentran las asignadas al Servicio.

Por otro lado, el grado de especificidad de los antecedentes requeridos por el Servicio en el requerimiento o en la citación, no puede implicar que aquellos no requeridos expresamente puedan omitirse en la fiscalización y reservarse para instancias subsecuentes -incluso con la aptitud de revertir las conclusiones del Servicio en sus actos terminales-, pues es en la etapa de fiscalización donde el contribuyente debe acreditar su situación tributaria. Resulta suficiente la especificidad consistente en que el Servicio comunique al contribuyente el impuesto y periodo a ser fiscalizado, para que el contribuyente identifique qué antecedentes necesarios debe acompañar.

Bajo esta perspectiva, la decisión del contribuyente de no comparecer o de no aportar antecedentes en este procedimiento, implica, por un lado, una autorización de aquel para que el Servicio determine legalmente las obligaciones tributarias con los antecedentes con que cuente, consolidando de manera definitiva las obligaciones tributarias de los contribuyentes; pero además, implica una ren uncia de su derecho de aportar pruebas sobre las obligaciones tributarias ya consolidadas por el Servicio, en las instancias de impugnación subsecuentes, sea esta en la instancia de reposición administrativa ante el Servicio como en la reclamación tributaria ante el TTA.

De acuerdo a esta nueva concepción del procedimiento de auditoría como el único instrumento para fiscalizar y determinar las obligaciones tributarias, es posible a su vez determinar correctamente la función de los órganos de revisión de los actos que el Servicio emite al final del mismo. De esta manera, si bien tales órganos poseen la competencia denominada de "plena jurisdicción", ya no acotada a una mera revisión de la legalidad de los actos del Servicio, dicha competencia debe limitarse a la prueba aportada en la etapa de fiscalización, pues tales instancias de impugnación deben encuadrarse en las denominadas de «apelación limitada». Inclusive, estas instancias pueden interpretar que la decisión voluntaria del contribuyente de no aportar pruebas en la instancia de fiscalización, constituyen conductas contrarias a la buena fe procesal, según se explicó.

Los órganos que conozcan las impugnaciones de los contribuyentes tendrán la obligación de limitar la incorporación de pruebas en sus res- 
pectivas instancias, analizando caso a caso qué pruebas debieron ser presentadas dentro del procedimiento de auditoría tributaria, bajo un criterio que considere las características del contribuyente, el tipo de impuesto, periodo y el conocimiento del acto o contrato objeto de fiscalización. De acuerdo a este criterio, incluso resulta admisible que el juez en el reclamo o resolutor en la impugnación administrativa deniegue la incorporación de pruebas que no fueron solicitadas por el Servicio en forma determinada y específicamente en la instancia de fiscalización, pero que no obstante debieron acompañarse, en atención a que eran necesarios y suficientes para acreditar una situación tributaria y que el contribuyente debía conocer y tener a disposición y al día por obligación legal.

En el caso del procedimiento de reclamo tributario ante el TTA, es posible concebir un correcto sentido y alcance de las normas probatorias contenidas en los artículos 21 y 132 inciso undécimo del Código Tributario, cuya interpretación literal impedía hasta ahora adecuarse al objeto del procedimiento tributario, y las demás instancias jurisdiccionales. De esta manera, debe entenderse que la regla impeditiva del inciso undécimo del artículo 132 del Código Tributario, simplemente reitera la regla general de que el contribuyente debe probar únicamente en la instancia de auditoría tributaria y no en las etapas posteriores de impugnación, y que se dispone para el caso puntual de que el Servicio haya exigido un antecedente específico en una citación, de manera que no constituye una excepción o restricción alguna que implique entender que a falta de especificación, siempre puedan acompañarse pruebas en las etapas de impugnación. Admitir lo contrario implica desatender el fin y función del procedimiento de auditoría tributaria, y la obligación legal que tiene el contribuyente de probar en ella, y dentro de plazos legales y fatales, su situación tributaria.

Finalmente, la preclusión del derecho a la prueba en instancias de impugnación, no constituye ninguna transgresión a derechos y garantías de tutela efectiva y debido proceso, pues el contribuyente cuenta con tales derechos, si bien dentro del procedimiento de auditoría tributaria. Este entendimiento permite garantizar el respeto a las distintas funciones de los órganos intervinientes, el buen uso de los recursos públicos e igualmente la certeza jurídica y celeridad tanto para Estado como para los contribuyentes respecto de su situación tributaria.

\section{BibLIOGRAFÍA}

Allesch, Johan y Obando, Iván, El Amparo del Derecho de Acceso a la Información

Pública, en Revista Ius et Praxis 11 (2005) 2, pp. 103-155.

Aróstica, Iván, La motivación de los actos administrativos en el Derecho Chileno, en 
Revista de Derecho de la Pontifica Universidad Católica de Valparaiso 10 (1986), pp. 499.520.

BENAVIDES, Álvaro, La procedencia de la nueva auditoría en el procedimiento general de reclamaciones, en Revista de Estudios Tributarios 12 (2015), 289-317.

CARRETTA, Francesco, Deberes procesales de las partes en el proceso civil chileno: referencia a la buena fe procesal y al deber de coherencia, en Revista de Derecho (Valdivia) 21 (2008) 1, pp. 101-127.

Chiovenda, Giuseppe, Instituciones de Derecho Procesal Civil (traducción de G. Orbaneja, Madrid, Editorial Revista de Derecho Privado, 1936).

Claro Solar, Luis, Explicaciones de derecho civil chileno y comparado (Santiago, Editorial Jurídica de Chile, 2013).

Comadira, Julio, Procedimientos Administrativos (Buenos Aires, Editorial La Ley, 2002).

CORDERo, Luis, El procedimiento administrativo (Santiago, Editorial Lexis Nexis, 2003).

Couture, Eduardo, Sobre el precepto nemo tenetur edere contra se, en Revista de Derecho Procesal (1943), pp. 53-71.

Couture, Eduardo, Fundamentos de Derecho Procesal Civil (Buenos Aires, Editorial Depalma, 1958).

De la Oliva, A., Diez-Picazo, I., Vegas, J., y Banacloche, J. , Derecho Procesal. Introducción (segunda edición, Madrid, Centro de Estudios Ramón Aceres, 2001).

FERRADA, Juan, Las potestades y privilegios de la administración pública en el régimen administrativo chileno, en Revista de Derecho 10 (2007) 2, pp. 69-94.

FERRADA, Juan, Los procesos administrativos en el derecho chileno, en Revista de Derecho de la Pontificia Universidad Católica de Valparaíso 36 (2011) 1, pp. 251-277.

GALÁn, Pedro. 1981. La prueba en segunda instancia.

(visible en http://www.mjusticia.gob.es/cs/Satellite/Portal/)

GANDUlFo, Eduardo, Sobre preclusiones procesales en el derecho chileno en tiempo de reformas. Ensayo de una teoría general desde un enfoque valorativo, en Ius et Praxis 15 (2009) 1, pp. 121-189.

GARCIMARTín, Regina. 2011. Orden y preclusión en las comparecencias en los procesos civiles. (visible en en http://www.uv.es/coloquio/coloquio/comunicaciones/ cp10garm.pdf)

Grampert, M. 2002. Tax Audit.

[visible en internet: http://www.worldbank.org]

GuZmán, Alejandro, La buena fe en el Código Civil de Chile, en Revista Chilena de Derecho 29 (2002) 1, pp. 11-23.

IRURETA, Pedro, Vigencia del principio de la buena fe en el derecho del trabajo chileno, en Ius et Praxis 17 (2011) 2, pp. 133-188.

Liebman, Enrico, Manual de Derecho Procesal Civil (Buenos Aires, Editorial EJEA, 1980).

MAIER, Julio, Derecho procesal penal argentino (Buenos Aires, Editorial Hamurabi, 1989).

Massone, Pedro, Principios de derecho tributario (Santiago, Editorial Edeval, 1979).

Montero, Juan, Los principios politicos de la nueva Ley de Enjuiciamiento Civil. Los poderes del juez y la oralidad (Valencia, Editorial Tirant lo Blanch, 2001).

MuÑOZ, Fernando, Estándares conceptuales y cargas procesales en el litigio antidiscriminación. Análisis crítico de la jurisprudencia sobre Ley Zamudio entre 2012 y 2015, en Revista de Derecho (Valdivia) 28 (2015) 2, pp. 145-167. 
Palomo, Diego, Apelación, doble instancia y proceso civil oral. A propósito de la reforma en trámite, en Estudios Constitucionales 8 (2010) 2, pp. 465-524.

PICÓ, Joan, El principio de la buena fe procesal (Barcelona, Editorial Bosch, 2003).

Rosenberg, Leo, La carga de la prueba (2a edición, Montevideo, Editorial B de F, 2002).

RuAY, Francisco, Análisis crítico sobre la inclusión del principio de buena fe procesal en el proyecto de código procesal civil chileno, en Revista Chilena de Derecho y Ciencia Politica 4 (2013) 3, pp. 53-82.

SÁncheZ, José, Teoría y práctica de la auditoría (Madrid, Editorial CDN, 1996).

Silva Cimma, Enrique, Derecho administrativo chileno y comparado (cuarta edición, Santiago, Editorial Jurídica de Chile, 1992).

Silva Cimma, Enrique, Derecho Administrativo chileno y comparado. Actos, contratos y bienes (Santiago, Editorial Jurídica de Chile, 2001).

Stoenrel, Carlos, De las disposiciones comunes a todo procedimiento y de los incidentes (Santiago, Editorial Jurídica de Chile, 2010).

Ugalde, Rodrigo y García, Jaime, Tribunales Tributarios y Aduaneros (Santiago, Editorial Legal Publishing, 2011).

VAlLINES, Enrique, La preclusión en el proceso civil (Madrid, Editorial Civitas, 2004).

VALlote, Daniel, Abuso del proceso por las partes, presupuestos generales, en XXI Congreso Nacional de Derecho Procesal Universidad Católica de Cuyo (2001) pp. 267-285.

Vergara, Alejandro, Control Judicial de la Motivación de los actos administrativos, en Temas de Derecho Universidad Gabriela Mistral 6 (1991) 2, pp. 117-144.

VIEHWEH, Theodor, Tópica y Jurisprudencia (traducción de L.D.P. León, Madrid, Editorial Taurus, 1963).

ZuRITA, Milenko, El acto administrativo tributario (Santiago, Editorial Libromar, 2013). 